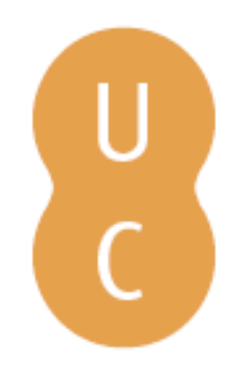

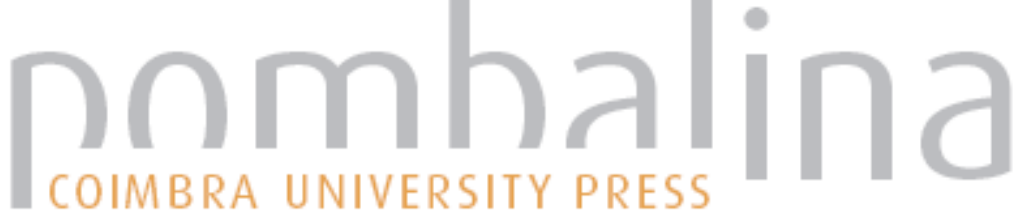

\section{Modeling fire behaviour and carbon emissions}

Autor(es): $\quad$ Groot, William J. de; Cantin, Alan S.; Jurko, Natasha; Newbery, Alison

Publicado por: Imprensa da Universidade de Coimbra

URL

persistente:

URI:http://hdl.handle.net/10316.2/34353

DOI:

DOI:http://dx.doi.org/10.14195/978-989-26-0884-6_132

Accessed : $\quad$ 26-Apr-2023 16:35:09

A navegação consulta e descarregamento dos títulos inseridos nas Bibliotecas Digitais UC Digitalis, UC Pombalina e UC Impactum, pressupõem a aceitação plena e sem reservas dos Termos e Condições de Uso destas Bibliotecas Digitais, disponíveis em https://digitalis.uc.pt/pt-pt/termos.

Conforme exposto nos referidos Termos e Condições de Uso, o descarregamento de títulos de acesso restrito requer uma licença válida de autorização devendo o utilizador aceder ao(s) documento(s) a partir de um endereço de IP da instituição detentora da supramencionada licença.

Ao utilizador é apenas permitido o descarregamento para uso pessoal, pelo que o emprego do(s) título(s) descarregado(s) para outro fim, designadamente comercial, carece de autorização do respetivo autor ou editor da obra.

Na medida em que todas as obras da UC Digitalis se encontram protegidas pelo Código do Direito de Autor e Direitos Conexos e demais legislação aplicável, toda a cópia, parcial ou total, deste documento, nos casos em que é legalmente admitida, deverá conter ou fazer-se acompanhar por este aviso. 


\section{ADVANCES IN}

Forest Fire

\section{RESEARCH}

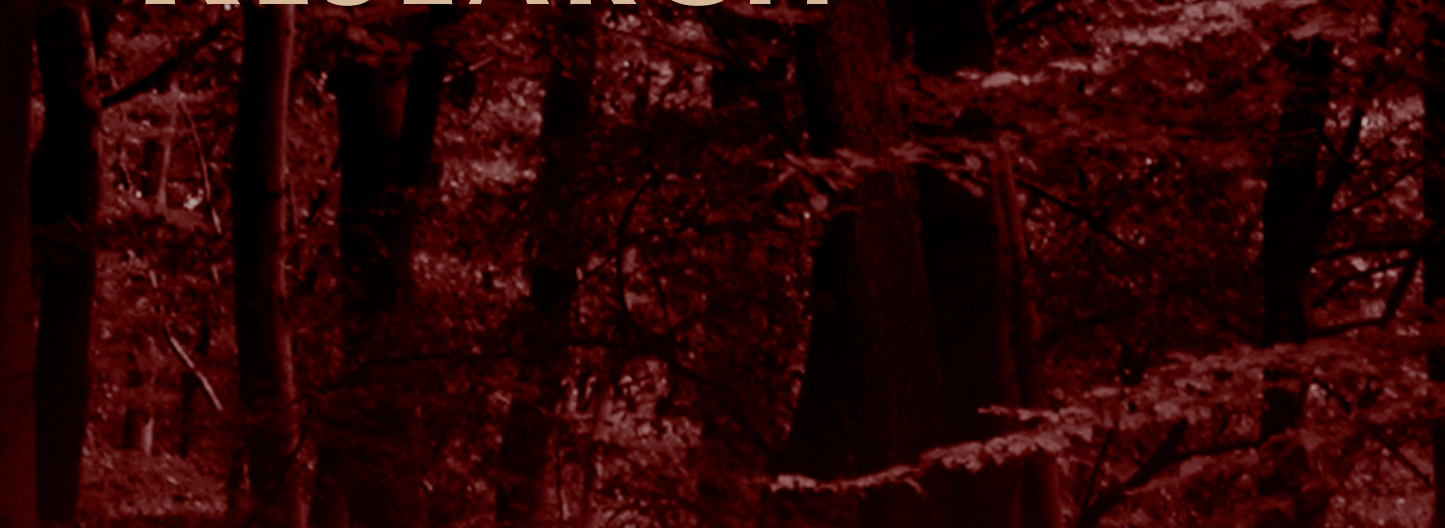

\section{DOMINGOS XAVIER VIEGAS}

\section{EDITOR}




\title{
Modeling fire behaviour and carbon emissions
}

\author{
William J. de Groot, Alan S. Cantin, Natasha Jurko, Alison Newbery \\ Canadian Forest Service, 1219 Queen St. E., Sault Ste. Marie, ON Canada P6A 2E5. \\ bill.degroot@nrcan.gc.ca, alan.cantin@nrcan.gc.ca, natasha.jurko@nrcan.gc.ca, \\ alison.newbery@nrcan.gc.ca
}

\begin{abstract}
Wildland fire is an important component of the earth system and global carbon cycle, burning about $350 \mathrm{M}$ ha of vegetated land and contributing $2.0 \mathrm{Pg} \mathrm{C}$ to the atmosphere in direct emissions every year. Wildland fire carbon emissions are directly related to fuel consumption, which is a key component of fire behaviour. Fuel consumption varies greatly by fuel (vegetation type, load, size, spatial distribution, moisture content) and weather (temperature, relative humidity, wind speed, rainfall) parameters. In forested regions where wildfires may burn for extended periods of time, carbon emissions can vary by an order of magnitude between stands within a single fire due to complex fuel structures and distribution patterns, and constantly changing fire weather conditions. Modelling stand-level fire behaviour and carbon emissions and compiling simulation results over large areas is commonly used as a bottom-up approach to summarizing fire regimes and estimating wildland fire emissions at large scales.

This paper presents a summary of studies simulating stand-level fire behaviour and carbon emissions using the Canadian Fire Effects Model (CanFIRE). CanFIRE simulates fire behaviour in standing timber, grass, and slash vegetation types, or combinations of these vegetation types. In standing timber vegetation types, the forest stand is simulated as 3 distinct fuel components: forest floor (herbaceous plant, litter and organic soil layers), surface fuels (dead woody debris), and overstory (tree) fuels. Modelled fire behaviour and carbon emission results from studies in various global regions of different vegetation types and climate zones are presented, including comparisons using different fuels and weather/climate datasets and comparison to other carbon emission estimation methods. Sensitivity of the model outputs to driving input variables is presented. In particular, the influence of stand composition, structure, surface fuel load and distribution, and organic soil characteristics are reviewed. Annual and seasonal trends in fire behaviour and carbon emissions are also presented. Recommendations for basic data standards to provide reliable and consistent modelling results are discussed.
\end{abstract}

Keywords: Canadian Fire Effects Model, crowning, fire intensity, forest carbon, fuel consumption, rate of spread, wildland fire emissions, North American forest regions, circumpolar boreal forest

\section{Introduction}

Numerous studies have been conducted over the last decade to estimate wildland fire carbon emissions using various models and methods (e.g., French et al. 2011). Global-level estimates have been produced using the Global Fire Emissions Database (GFED3) (Van der Werf 2010). At national and sub-national scales, wildfire carbon emissions are typically estimated using a fire behaviour-based, bottom-up method using models such as the Canadian Fire Effects Model (CanFIRE, de Groot 2006, 2010), the First Order Fire Effects Model (FOFEM, Reinhardt et al. 1997), CONSUME (Ottmar et al. 2009) and the Wildland Fire Emissions Information System (WFEIS, French et al. 2009), which is based on the CONSUME model. These models quantify fuel consumption at the stand level and scaleup by aggregating stand emissions data over landscapes with fire mapping products (e.g., de Groot et al. 2007, French et al. 2011) Stand-level fuel consumption can be calculated with fuels data from a variety of sources and spatial resolution, and fire weather data with a range of spatial and temporal resolutions. Using different databases with various scales contributes to the variability of wildland fire carbon emission estimates that are produced (c.f., French et al. 2011). Adding to this uncertainty is that there are very few verified field data sources to compare with modelled results (Ottmar 2014). 
The purpose of this paper is to review applications of the Canadian Fire Effects Models to estimate carbon emissions in the circumpolar boreal forest region, in North American forests (including boreal and western forest regions), and within the Canadian boreal forest region, and to compare results using different fuels and weather data bases at different scales.

\section{The Canadian Fire Effects Model}

The Canadian Fire Effects Model (CanFIRE) is an integrated science-management model of the Canadian Forest Fire Danger Rating System (Stocks et al. 1989). It was originally developed as the Boreal Fire Effects Model (BORFIRE) to conduct fire, climate change, and vegetation dynamics research in the Canadian boreal forest (de Groot et al. 2002, 2003). The model was later expanded to include all Canadian forest regions (renamed CanFIRE) for use as an operational model to calculate annual national wildland fire carbon emissions (de Groot 2006, de Goot et al. 2007). The model has since been re-designed for fire and forest management applications and is available as an Excel spreadsheet $^{1}$, a cross-platform Windows and Unix application ${ }^{1}$, and as a web application ${ }^{2}$.

CanFIRE simulates stand-level physical and ecological fire effects. It is a fire behaviour-based model driven by fuels and fire weather data. Fuels are characterized by tree species in the stand (including age, height, dbh, and density data) and fuel loads for stand components of the forest floor (litter and other fine fuels, fermentation, and humus layers), dead and downed woody debris (multiple roundwood diameter size classes), and aboveground tree biomass (live and dead; stem, branch, bark and foliage components). Fire weather data are provided to CanFIRE using the Canadian Forest Fire Weather Index (FWI) System (Van Wagner 1987) components. The model calculates fire behaviour (rate of fire spread, fuel consumption, type of fire, and fire intensity) and resulting physical (depth of burn, crown scorch, carbon emissions) and ecological (tree mortality/survival, regeneration rate, long-term post-fire succession) effects. CanFIRE uses the rate of spread algorithms of the Canadian Forest Fire Behavior Prediction (FBP) System (Forestry Canada Fire Danger Group 1992); type of fire is determined using Van Wagner's (1977) crown fire threshold model; fuel consumption is calculated using fuel load data and new fuel consumption algorithms (de Groot et al. 2009); and resulting fire intensity is calculated using Byram's (1959) equation. CanFIRE can be used to simulate fire behaviour and effects of a single fire event, or the accumulated effects of many fires occurring over many years on a defined landscape (i.e., simulating fire regime).

CanFIRE has been modified and used for numerous fire and carbon modelling applications in different regions since the original BORFIRE model. The purpose of this paper is to provide a review of CanFIRE applications to estimate wildland fire carbon emissions using different data sources and simulation methods, and to compare with results from other emission models.

\section{Wildland Fire Carbon Emission Studies with CanFIRE}

\section{Circumpolar Boreal Fire Carbon Emissions}

A comparison of wildfire carbon emissions in western Canada and central Siberia, Russia during 20012007 was conducted with remotely-sensed area burned polygons and fire weather data used to simulate fire behaviour and carbon emissions with CanFIRE (de Groot et al. 2013a). Russia-specific fuel models were setup in CanFIRE by assigning an FBP System fuel type, and adjusting tree heights and crown length factors for Russian tree species. The primary effect of this was to adjust the crown fire

\footnotetext{
${ }^{1}$ Contact Bill de Groot (bill.degroot@nrcan.gc.ca) or Alan Cantin (alan.cantin@nrcan.gc.ca)

${ }^{2}$ http://www.glfc.forestry.ca/canfire/index.cfm
} 
threshold for Russian boreal tree species. Fuels load and type data were obtained from national sources and fires were mapped with different remote sensing products. As a result, input data had different spatial characterization and resolution. However, the data was sufficient to calculate stand-level fire behaviour for all large (>200ha) fires in both study areas for the 7-year period. All fires were burned using fire weather conditions interpolated from station data to all MODIS hot spots within a $1 \mathrm{~km}$ buffer around each fire and taking the mean, thus weighting the fire weather to the date of greatest fire activity. Results of the study comparison indicated divergent continental fire regimes in the circumpolar boreal region, which was attributed to differences in tree species morphology and fire ecology traits. In particular, the fire regime of the Canadian study area was characterized by infrequent, very large, high intensity crown fires; whereas, the Russian study area was characterized by moderately frequent, large surface fires of moderate to high intensity (Table 1). Fire seasons were also different with most large fires occurring in Russia in the spring, and during summer in Canada. The carbon emissions rate ( $\mathrm{t} \mathrm{C} \cdot \mathrm{ha}^{-1}$ within burned area polygons) in Canada was $50 \%$ higher than in Russia mostly because of higher forest floor fuel loadings and fuel consumption but also, to a lesser degree, due to higher crown fuel consumption rates in Canada. However, the total $\mathrm{C}$ emissions rate $\left(\mathrm{t} \mathrm{C} \cdot \mathrm{ha}^{-1}\right.$ per 100 $\mathrm{M}$ ha of forest area) was two times greater in Russia because of the much higher annual area burned rate.

CanFIRE was also used to simulate $\mathrm{C}$ emissions in the same Canadian and Russian study areas under future climate change scenarios (de Groot et al. 2013b). That study examined the impact of changing fire weather on carbon emissions by the end of this century. Three Global Climate Models (Canadian CGCM3.1, HadCM3, and IPSL-CM4) and three climate change scenarios (A1B, A2, and B1) (IPCC 2000) were used to determine nine sets of future fire weather conditions for the CanFIRE simulations. All climate change models and scenarios indicated greater fire weather severity across the circumboreal region, although conditions will be slightly more severe in the western Canada study area. The future fire season will have two extreme fire intensity peaks in western Canada in spring and later summer, and one extreme peak in central Russia in late spring/early summer. Higher carbon emission rates $\left(\mathrm{t} \mathrm{C} \cdot \mathrm{ha}^{-1}\right)$ will occur in western Canada due to a higher fuel consumption rate but central Russia will have greater total carbon emission rates $\left(\mathrm{t} C \cdot \mathrm{ha}^{-1}\right.$ per $100 \mathrm{M}$ ha forest area) due to higher annual area burned rates.

Table 1. Summary of annual average fire regime characteristics in western Canada and central Russia boreal forest during 2001-2007 (de Groot et al. 2013a)

\begin{tabular}{lcc} 
& Canadian Study Area & Russian Study Area \\
\hline Number of fires (per 100 M ha forest) & 93.7 & 1441.9 \\
Area burned (M ha/100 M ha forest) & 0.56 & 1.89 \\
Mean fire return interval (yrs) & 179.9 & 52.9 \\
Large fire size (ha) & 5930 & 1312 \\
Crown fire (\%) & 57.1 & 6.5 \\
Head fire intensity $(\mathrm{kW} / \mathrm{m})$ & 6017 & 4858 \\
Fuel consumption $\left(\mathrm{kg} / \mathrm{m}^{2}\right)$ & 5.68 & 3.73 \\
C emissions rate $(\mathrm{t} / \mathrm{ha})$ & 28.4 & 18.5 \\
Total C emissions rate $(\mathrm{Mt} / 100 \mathrm{M}$ ha forest) & 15.8 & 35.0 \\
\hline
\end{tabular}

\section{North American Wildland Fire Carbon Emissions}

In a study of six terrestrial models, French et al. (2011) compared wildland fire carbon emissions from five large fires across North America. CanFIRE was applied to the three forest-dominated fires of that study, but not to the two fires in southern California chaparral because CanFIRE does not currently 
have a shrub fuel model. Fuels data for the large fires in Oregon and Alaska were provided from the Fuels Characteristic Classification System (FCCS, Ottmar et al. 2007) and from fuel load models of Lutes et al. (2009). Fuels data in the Saskatchewan large fire were obtained from provincial forest inventory and interpreted as FCCS fuels. All fires burned over many days and were simulated in CanFIRE and WFEIS as multi-day events using daily fire progression (as determined by MODIS hot spots) and daily fire weather data. Additional WFEIS, CONSUME and FOFEM estimates were obtained using single day simulations with standard fuel moisture scenarios. FBP estimates were multiple day simulations using FBP System fuel types interpreted from the FCCS data (Oregon and Alaska) or forest inventory data (Saskatchewan).

Despite using the same original fuels and weather databases, emission estimates showed considerable variation depending on model and fire location. A detailed field-based survey of carbon emissions was available for the Oregon Biscuit fire (Campbell et al. 2007), which reported an average carbon emissions rate of $1.9 \mathrm{~kg} \mathrm{C} \cdot \mathrm{m}^{-2}$. The CanFIRE estimate was $3 \%$ higher, and FOFEM 5.7 ranged from $17 \%$ lower to $4 \%$ higher ( 3 scenarios using revised fuels map); the FBP System was $11 \%$ lower, GFED was $14 \%$ higher, CONSUME 3.0 was 10-30\% lower (3 scenarios using revised fuels map), and WFEIS was $61-63 \%$ higher (3 scenarios using revised fuels map). A field-based survey was also available for the Alaska Boundary fire, resulting in an emissions rate of $2.59 \mathrm{~kg} \mathrm{C} \cdot \mathrm{m}^{-2}$. For that fire, the GFED estimate was $14 \%$ lower, CONSUME was 10-45\% lower, CanFIRE was $40 \%$ higher, the FBP System was 48\% lower, and FOFEM was 73-136\% higher. Field data were not available for the Saskatchewan Montreal Lake fire for comparison, but the estimated emission rates were $0.79 \mathrm{~kg} \mathrm{C} \cdot \mathrm{m}^{-2}(\mathrm{FBP}), 1.26$ $\mathrm{kg} \mathrm{C} \cdot \mathrm{m}^{-2}$ (GFED), $1.6 \mathrm{~kg} \mathrm{C} \cdot \mathrm{m}^{-2}$ (WFEIS), $2.32 \mathrm{~kg} \mathrm{C} \cdot \mathrm{m}^{-2}$ (CanFIRE), $2.23-3.32 \mathrm{~kg} \mathrm{C} \cdot \mathrm{m}^{-2}$ (CONSUME), and 4.76-6.51 $\mathrm{kg} \mathrm{C} \cdot \mathrm{m}^{-2}$ (FOFEM). A previous estimate for the same fire using CanFIRE and national forest inventory data (Power and Gillis 2006) was $1.70 \mathrm{~kg} \mathrm{C} \cdot \mathrm{m}^{-2}$, and using the national fuels database (Nadeau et al. 2005) with the FBP System was $1.20 \mathrm{~kg} \mathrm{C} \cdot \mathrm{m}^{-2}$.

\section{Canadian Wildland Fire Carbon Studies}

CanFIRE has been used operationally since 2004 to calculate annual national wildland fire carbon emissions as part of the National Forest Carbon Monitoring, Accounting and Reporting System (Kurz and Apps 2006) to meet United Nations Framework Convention on Climate Change and other international reporting obligations (de Groot et al. 2007). CanFIRE was modified to utilize a national database of carbon pools provided by the Carbon Budget Model of the Canadian Forest Sector (CBMCFS3, Kurz et al. 2009) as a replacement for fuel type and fuel load data. This is a spatially-explicit procedure using primarily satellite-mapped burned areas, daily hot spots and fire weather data. In brief, every forest stand within each mapped fire perimeter was burned in the model as a single-day event. Fire weather was calculated by interpolating FWI System values to each MODIS and AVHRR hot spot, and averaging all those data annually for the fire season for each ecoregion-provincial unit, and applying those results to all fires contained in each unit. In this way, the FWI system data are weighted by days of highest fire activity within the ecoregion-provincial unit for the year.

More recently, 43 large fires from Ontario, Saskatchewan, Alberta, and British Columbia were used in an ongoing study to compare Canadian wildland fire carbon emissions using different fuels data and simulation methods. The initial phase of the study examined 24 large boreal wildfires from 2006-2008 ranging in size 95-62,670 ha. These fires were selected because they occurred in areas where detailed provincial forest inventory data were available, which allowed stand-level simulations with CanFIRE to calculate direct carbon emissions. In a second analysis, an additional 10 large fires (446-22,116 ha) occurred in Alberta during the same time period and were combined with the original 24 fires plus 9 large fires from 2010 (1,943-28,182 ha) in British Columbia and used for carbon emission calculations using the national fuel type map of Nadeau et al. (2005) (resolution of $1 \mathrm{~km}^{2}$ ) and standard fuel loads for FBP System fuel types. The fires were simulated as a single-day event (date selected by weighted average of hot spots), and as a multi-day event (daily fire spread using hot spots) for comparison. 
Results using the large scale national fuels database ( $\mathrm{n}=43$ fires) and standard FBP System fuel types and fuel loads showed very little difference when using single- or multi-day simulations (Figure 1). Emissions were generally higher in Alberta and lower in Ontario. In the comparison of 33 fires with forest inventory available to use as input fuels data (Figure 2), carbon emission estimates increased for the British Columbia fires and decreased for all others, including a very sharp decrease in the Alberta and Saskatchewan fires (although there were only two large fires in Alberta with forest inventory available). These results were consistent for both single- and multi-day simulations. When all provincial data were combined, the forest inventory method produced lower carbon emissions estimates than the FBP method. Overall, there was almost no difference between single- and multiday estimates (Figure 3).

\section{Discussion}

The previous studies using CanFIRE to estimate wildland fire carbon emissions have demonstrated that many different fuel and weather data sets can be used as input variables to CanFIRE (Table 2). The question of which database and/or what data resolution is the most appropriate or accurate to use is still not clear. As Ottmar (2014) pointed out, there are very few datasets available to test model accuracy, and there is also very little information available about the sensitivity of models to data input variability.

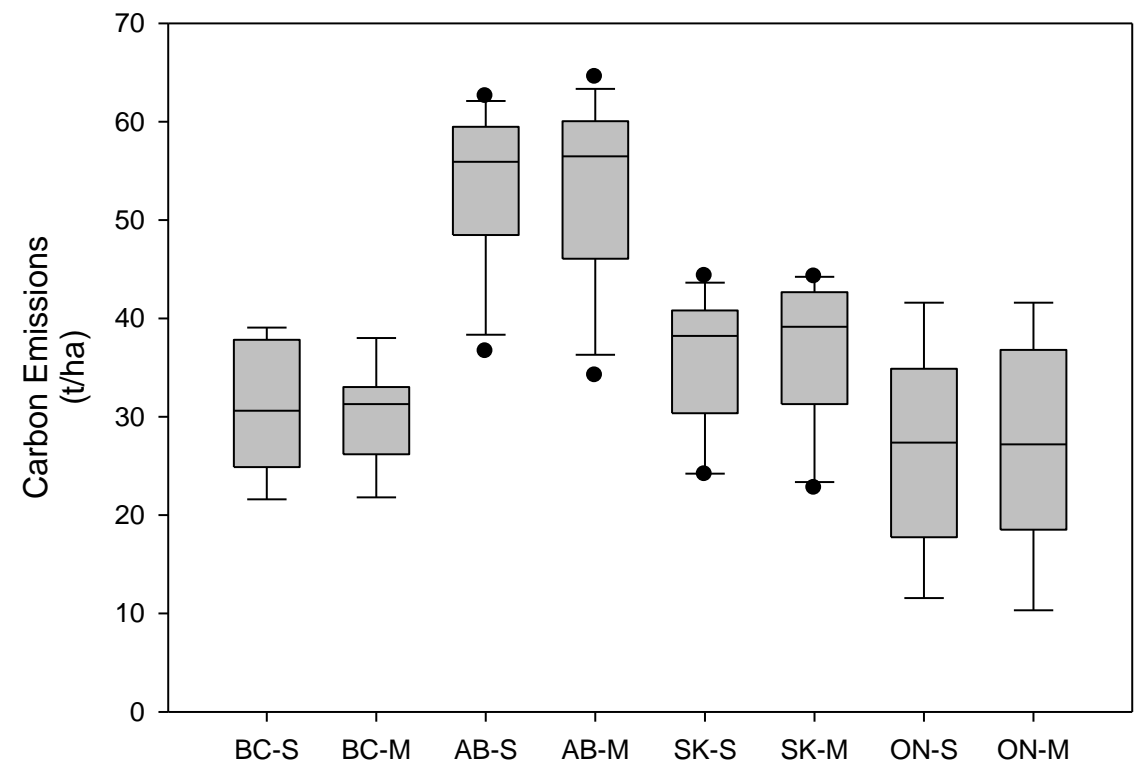

Fig 1. Summary of wildland fire carbon emissions in the provinces of British Columbia (BC) (n=9), Alberta (AB) $(n=12)$, Saskatchewan $(S K)(n=13)$, and Ontario $(O N)(n=9)$ using single-day $(S)$ and multi-day (M) simulation methods with CanFIRE. Fuels data were obtained from the spatial national fuel type map of Nadeau et al. (2005) using standard fuel loads for FBP System fuel types. 


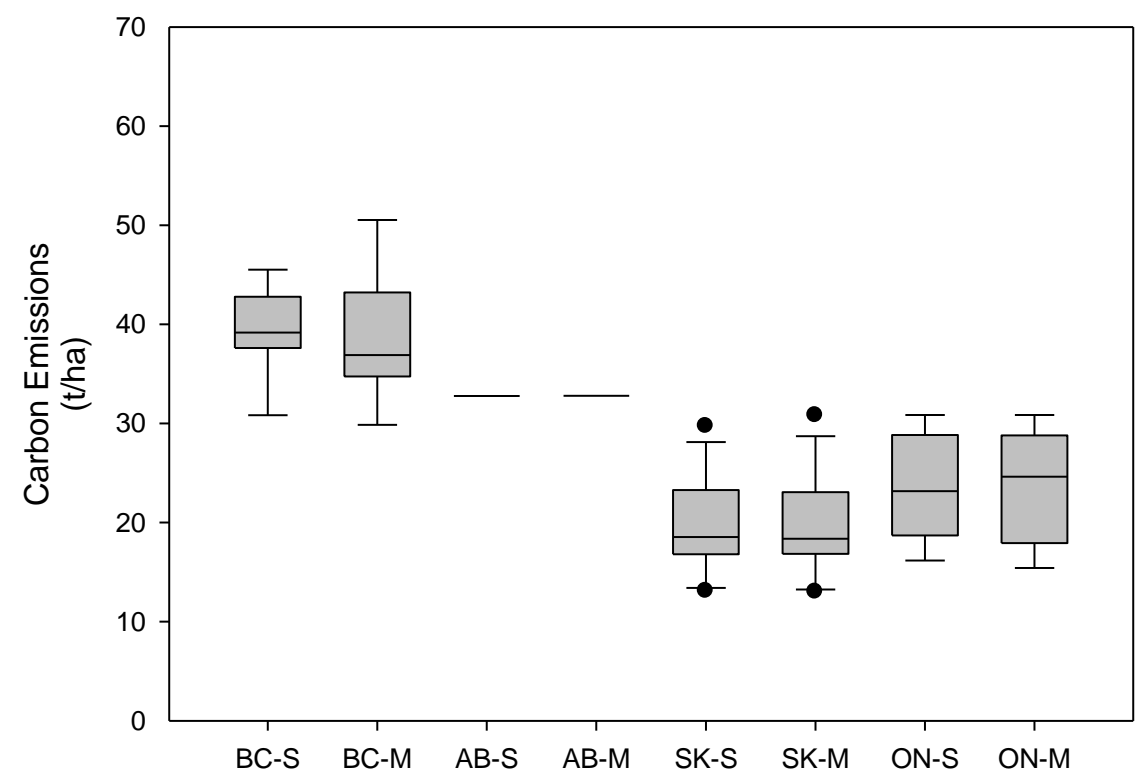

Fig 2. Summary of wildland fire carbon emissions in the provinces of British Columbia (BC) (n=9), Alberta (AB) $(n=2)$, Saskatchewan $(S K)(n=13)$, and Ontario $(O N)(n=9)$ using single-day $(S)$ and multi-day (M) simulation methods with CanFIRE. Spatial provincial forest inventory was used to interpret stand-level species composition and corresponding fuel load was calculated using forest inventory with provincial growth and yield models.

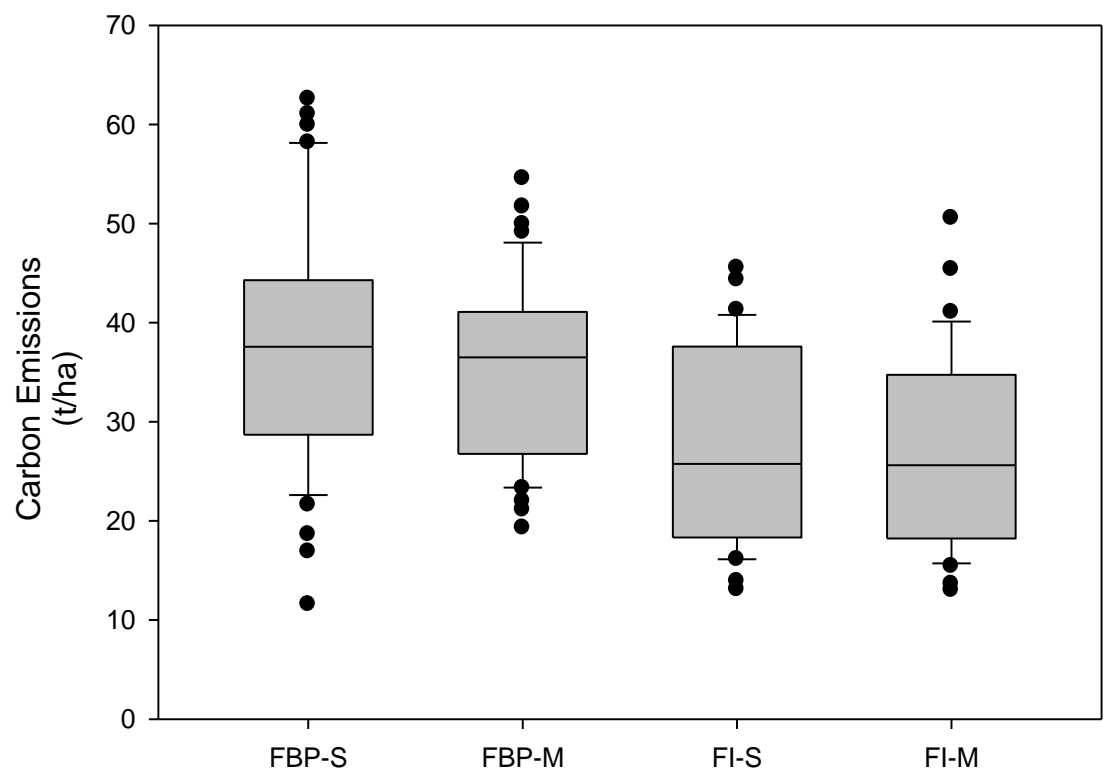

Fig 3. Summary of average wildland fire carbon emissions in the provinces of British Columbia, Alberta, Saskatchewan, and Ontario using the national fuels database (FBP) and provincial forest inventory (FI) for fuels information, and using single-day $(S)$ and multi-day $(M)$ simulation methods with CanFIRE.

One of the most important observations in comparing these wildland fire carbon emissions studies is the influence of fuels input data. The CanFIRE estimate of emissions on the Montreal Lake fire in French et al. (2011) was almost twice as high as the previous estimate in de Groot et al. (2007), which was entirely the result of different input fuels data. Similarly, emission estimates using CONSUME 
and FOFEM on the Biscuit fire were up to three times higher for the same model, depending on the fuels data source (original and revised fuels maps; French et al. 2011). The impact of different fuels data on emission estimates was also identified in the circumboreal comparison study (de Groot et al. 2013a), which showed substantially higher carbon emissions rates ( $\mathrm{t} / \mathrm{ha}$ ) from Canadian fires than Russian fires. That result was attributed to underestimated forest floor fuel loads in the Russian database because fire weather conditions were fairly similar.

French et al. (2011) provide a good summary of differences in the six tested models that can lead to different emission estimates. In that study, emission estimates from a few models aligned fairly close on some fires but not on others, and there was no obvious overall trend. This suggests that wildland fire emission models may need to be regionally calibrated. However, one common result was that FBP System estimates were lower than most of the other model estimates. This agrees with previous results from de Groot et al. (2007) that indicated FBP System estimates were about 30\% lower than CanFIRE estimates in central Canada. Low emission estimates from the FBP System are attributed primarily to an underestimation of forest floor fuel consumption. CanFIRE uses more recent forest floor fuel consumption algorithms (de Groot et al. 2009) than currently included in the FBP System, but which will be incorporated in the next generation FBP System.

Table 2. Summary of fire simulation methods, weather and fuels data for wildland fire carbon emission studies using CanFIRE

\begin{tabular}{|c|c|c|c|c|c|}
\hline \multirow[t]{2}{*}{ Study } & \multirow{2}{*}{$\begin{array}{l}\text { Fire simulation } \\
\text { method }\end{array}$} & \multicolumn{2}{|c|}{ Weather data } & \multicolumn{2}{|c|}{ Fuels data } \\
\hline & & Source & Resolution & Source & Resolution \\
\hline \multirow[t]{2}{*}{$\begin{array}{l}\text { Boreal fire emissions } \\
\text { in Canadian and } \\
\text { Russian study areas } \\
\text { (2001-2007) } \\
\text { (de Groot et al. } \\
\text { 2013a, 2013b) }\end{array}$} & $\begin{array}{l}\text { Canadian large fires } \\
\text { burned as single } \\
\text { day events on most } \\
\text { active fire day (by } \\
\text { MODIS hot spots) }\end{array}$ & $\begin{array}{l}\text { Canadian } \\
\text { national } \\
\text { weather station } \\
\text { network }\end{array}$ & Daily & $\begin{array}{l}\text { National fuel } \\
\text { type map, } \\
\text { standard FBP } \\
\text { fuel loads }\end{array}$ & $1 \mathrm{~km}^{2}$ \\
\hline & $\begin{array}{l}\text { Russian large fires } \\
\text { burned as single } \\
\text { day events on most } \\
\text { active fire day (by } \\
\text { MODIS hot spots) }\end{array}$ & $\begin{array}{l}\text { Russian } \\
\text { national } \\
\text { weather station } \\
\text { networks }\end{array}$ & Daily & $\begin{array}{l}\text { National forest } \\
\text { carbon } \\
\text { database }\end{array}$ & $\begin{array}{l}\text { Ecoregion and } \\
\text { oblast-level } \\
\text { summaries } \\
\text { (semi-spatial) }\end{array}$ \\
\hline $\begin{array}{l}\text { North American } \\
\text { study } \\
\text { (French et al. 2011) }\end{array}$ & $\begin{array}{l}3 \text { large fires } \\
\text { (Oregon, Alaska, } \\
\text { Saskatchewan) } \\
\text { burned as single } \\
\text { and/or multi-day } \\
\text { events }\end{array}$ & $\begin{array}{l}\text { Nearby fire } \\
\text { weather } \\
\text { stations }\end{array}$ & Daily & $\begin{array}{l}\text { FCCS and } \\
\text { FLM }^{\mathrm{a}}\end{array}$ & $1 \mathrm{~km}^{2}$ \\
\hline $\begin{array}{l}\text { Canadian annual } \\
\text { carbon emissions } \\
\text { reporting } \\
\text { (de Groot et al. } \\
\text { 2007) }\end{array}$ & $\begin{array}{l}\text { All fires burned as } \\
\text { single day event } \\
\text { using averaged fire } \\
\text { weather from active } \\
\text { fire days }\end{array}$ & $\begin{array}{l}\text { National and } \\
\text { provincial fire } \\
\text { weather station } \\
\text { network }\end{array}$ & $\begin{array}{l}\text { Daily, averaged } \\
\text { seasonally by } \\
\text { hot spot } \\
\text { occurrence over } \\
\text { ecoregion- } \\
\text { provincial units }\end{array}$ & $\begin{array}{l}\text { CBM-CFS3 } \\
\text { carbon pools }\end{array}$ & Stand-level \\
\hline \multirow[t]{2}{*}{ Canadian large fires } & $\begin{array}{l}\text { Large fires burned } \\
\text { as single- and } \\
\text { multi-day events }\end{array}$ & $\begin{array}{l}\text { National and } \\
\text { provincial fire } \\
\text { weather station } \\
\text { networks }\end{array}$ & Daily & $\begin{array}{l}\text { National fuel } \\
\text { type map and } \\
\text { standard FBP } \\
\text { system fuel } \\
\text { loads }\end{array}$ & $1 \mathrm{~km}^{2}$ \\
\hline & $\begin{array}{l}\text { Large fires burned } \\
\text { as single- and } \\
\text { multi-day events }\end{array}$ & $\begin{array}{l}\text { National and } \\
\text { provincial fire } \\
\text { weather station } \\
\text { networks }\end{array}$ & Daily & $\begin{array}{l}\text { Provincial } \\
\text { forest } \\
\text { inventory }\end{array}$ & Stand-level \\
\hline
\end{tabular}

\footnotetext{
${ }^{a}$ Fuel Characteristic Classification System (Ottmar et al. 2007) and Fuel Loading Models (Lutes et al. 2009)
} 
The amount of detail (or scale) to use for wildland fire emissions modelling has been a lingering question. Forest inventories have many advantages as a fuels data source: they are small scale (standlevel), have detailed species information for fuel typing, integrate well with forest growth and yield models for dynamic fuel modelling, and integrate well with tree biomass algorithms to properly distribute fuel load in multiple stand components. However, there are many deficiencies: inventories are often old, they are only as reliable as the original photo interpretation and areas are so vast that ground checking is often limited, fuels data for some stand components are usually missing (e.g., forest floor and dead woody debris), inventory methods are usually not consistent across land jurisdictions which makes large scale simulation difficult, and there are many areas without forest inventory. There are numerous other vegetation, fuels, and biomass inventories that can be used for calculating wildland fire emissions, and all will produce different results. The question remains: what are the best criteria to use for selecting a fuels database, understanding that many factors have to be balanced (i.e, accuracy vs. efficiency)? It is still an open question because test datasets to assess accuracy are very few. However, large-scale data consistency is important in terms of modelling efficiency. At this point, the general recommendation is to use stand-level data if it is consistent in content across the simulation area, and if not available, then to use coarser resolution fuels data at a larger scale. To provide the best fire behaviour-based estimate of wildland fire carbon emissions, the selected fuels database should provide fuel type and load data that can be separated into discreet stand components (forest floor, dead woody debris, tree crown, etc.) in order to properly simulate stand-level fire behaviour dynamics.

In terms of temporal scale, the question of detail is much less critical. In the Canadian fire study, CanFIRE emission estimates showed very little difference between single- and multi-day simulations (Figure 1-3) even though some fires burned for over a month. The comparison of single- and multiday WFEIS simulations (French et al. 2011) also showed the same results. This suggests that the procedure used for single-day simulation (i.e., using fire weather and fuel moisture data based on dailyweighted hot spot occurrence) captures the most important weather information driving these fire behaviour-based models.

\section{Conclusions}

Fuels data source is a critical factor influencing wildland fire carbon emission estimates for all fire behaviour-based models, including CanFIRE. Consistency in data content across the simulation area is important, and it is preferable to have stand-level detail so that fuel load can be distributed in the different stand components. Multiple-day simulations of fire spread do not appear necessary, as singleday simulations using a hot spot-weighted average of daily fire weather provide very similar emission estimates.

\section{Acknowledgments}

We thank David McNeice for preparing the FBP System database; Nathan Sauvé for translating provincial inventory to CanFIRE input data; Edward Fong (Inventory Branch, BC Ministry of Forests) for providing VRI data; and Richard Carr and Peter Englefield (CFS) for providing FWI System data.

\section{References}

Byram GM (1959) Combustion of forest fuels. Forest Fire: Control and use. K. P. Davis. New York, McGraw-Hill.

Campbell J, Donato D, Azuma D, Law B (2007) Pyrogenic carbon emission from a large wildfire in Oregon, United States. Journal of Geophysical Research 112, G04014, doi:10.1029/2007JG000451. 
de Groot WJ (2006) Modeling Canadian wildland fire carbon emissions. Proceedings of the IV International Conference on Forest Fire Research (Nov. 2006, Coimbra, Portugal). D.X. Viegas, ed. CD-ROM. Elsevier BV: Amsterdam.

de Groot WJ (2010) Modeling fire effects: integrating fire behaviour and fire ecology. In: Viegas, D.X. (Ed.), VI International Conference on Forest Fire Research, ADAI/CEIF Univ. Coimbra, Portugal (CD ROM)

de Groot WJ, Bothwell PM, Carlsson DH, Logan KA (2002) Simulating the impacts of future fire regimes and fire management strategies on vegetation and fuel dynamics in western Canada using a boreal fire effects model (BORFIRE). CD-ROM in Proceedings of the IV International Conference on Forest Fire Research and Wildland Fire Safety Summit (Luso, Portugal). Viegas, D.X. (ed.). Millpress, Rotterdam.

de Groot WJ, Bothwell PM, Carlsson DH, Logan KA (2003) Simulating the effects of future fire regimes on western Canadian boreal forests. Journal of Vegetation Science 14, 355-364.

de Groot WJ, Landry R, Kurz WA, Anderson KR, Englefield P, Fraser RH, Hall RJ, Banfield E, Raymond DA, Decker V, Lynham TJ, Pritchard JM (2007) Estimating direct carbon emissions from Canadian wildland fires. International Journal of Wildland Fire 16, 593-606.

de Groot WJ, Pritchard J, Lynham TJ (2009) Forest floor fuel consumption and carbon emissions in Canadian boreal forest fires. Canadian Journal of Forest Research 39, 367-382.

de Groot WJ, Cantin AS, Flannigan MD, Soja AJ, Gowman LM, Newbery A (2013a) A comparison of Canadian and Russian boreal forest fire regimes. Forest Ecology and Management 294, 23-34.

de Groot WJ, Flannigan MD, Cantin AS (2013b) Climate change impacts on future boreal fire regimes. Forest Ecology and Management 294, 35-44.

French NHF, Erickson TA, McKenzie D, Billmire M, Hatt C (2009) The Wildland Fire Emissions Information System: Providing information for carbon cycle studies with open source GIS tools, paper presented at North American Carbon Program-2nd All-Investigators Meeting, San Diego, Calif.

French NHF, de Groot WJ, Jenkins LK, Rogers BM, Alvarado E, Amiro B, de Jong B, Goetz S, Hoy E, Hyer E, Keane R, Law BE, McKenzie D, McNulty SG, Ottmar R, Pérez-Salicrup DR, Randerson J, Robertson KM, Turetsky M (2011) Model comparisons for estimating carbon emissions from North American wildland fire. Journal of Geophysical Research 116, G00K05.

Forestry Canada Fire Danger Group (1992) Development and structure of the Canadian Forest Fire Behaviour Prediction System. Forestry Canada, Ottawa, ON. Inf. Rep. ST-X-3.

IPCC (2000) Emissions scenarios. Cambridge University Press, Cambridge.

Kurz WA, Apps MJ (2006) Developing Canada's national forest carbon monitoring, accounting and reporting system to meet the reporting requirements of the Kyoto Protocol. Mitigation and Adaptation Strategies for Global Change 11, 33-43. doi:10.1007/S11027-006-1006-6

Kurz WA, Dymond CC, White TM, Stinson G, Shaw CH, Rampley GJ, Smyth C, Simpson BN, Neilson ET, Trofymow JA, Metsaranta J, Apps MJ (2009) CBM-CFS3: a model of carbondynamics in forestry and land-use change implementing IPCC standards. Ecological Modelling 220, 480-504.

Lutes DC, Keane RE, Caratti JF (2009) A surface fuels classification for estimating fire effects. International Journal of Wildland Fire 18, 802-814, doi:10.1071/WF08062.

Nadeau LB, McRae DJ, Jin J-Z (2005) Development of a national fuel-type map for Canada using fuzzy logic. Natural Resources Canada, Canadian Forest Service, Inf. Rep NOR-X-406 (Edmonton, Alberta)

Ottmar RD (2014) Wildland fire emissions, carbon, and climate: Modeling fuel consumption. Forest Ecology and Management 317, 41-50.

Ottmar RD, Sandberg DV, Riccardi CL, Prichard SJ (2007) An overview of the Fuel Characteristic Classification System (FCCS) - Quantifying, classifying, and creating fuelbeds for resource planning. Canadian Journal of Forest Research 37, 2383-2393, doi:10.1139/X07-077. 
Ottmar RD, Miranda A, Sandberg D (2009) Characterizing sources of emissions from wildland fires, in Wildland Fires and Air Pollution, edited by A. Bytnerowicz et al., pp. 61-78, Elsevier, Amsterdam.

Power K, Gillis MD (2006) Canada's forest inventory 2001. Natural Resources Canada, Canadian Forest Service, Inf. Rep. BC-X-408E (Victoria, BC)

Reinhardt ED, Keane RE, Brown JK (1997) First Order Fire Effects Model: FOFEM 4.0, user's guide. USDA For. Serv., Washington, DC. Gen. Tech. Rep. INT-GTR- 344.

Stocks BJ, Lawson BD, Alexander ME, Van Wagner CE, McAlpine RS, Lynham TJ, Dube DE (1989) Canadian Forest Fire Danger Rating System: an overview. Forestry Chronicle 65, 258-265.

van der Werf GR, Randerson JT, Giglio L, Collatz GJ, Mu M, Kasibhatla PS, Morton DC, DeFries RS, Jin Y, van Leeuwen TT (2010) Global fire emissions and the contribution of deforestation, savanna, forest, agricultural, and peat fires (1997-2009). Atmospheric Chemistry and Physics 10, $11707-11735$.

Van Wagner CE (1977) Conditions for the start and spread of crown fire. Canadian Journal of Forest Research 7, 23-34.

Van Wagner CE (1987) Development and structure of the Canadian forest fire weather index system. Canadian Forest Service. Ottawa, Canada. For. Tech. Rep. 35. 